\title{
Assessing the Use of a Video to Teach the Laplace Expansion Theorem in Higher Education
}

\author{
Sidonie F. Costa
}

\begin{abstract}
The increasing use of learning videos in Higher Education (HE) have revolutionizing the traditional teaching environment.b-Mat@plicada is a b-Learning Mathematics course mainly composed of educational videos that the HE students of a Portuguese Institution can used for their study as a complement of the face-to-face lectures. In a previous research, an experiment was performed in the classroom context, where 49 HE students watched the b-Mat@plicada video on Matrix Multiplication as replacement of the traditional face-to-face explanation. Then, they were asked to solve individually an exercise, and respond to a survey assessing attitudes, perception, and satisfaction. In the present study, $63 \mathrm{HE}$ students participated to a similar experiment with the b-Mat@plicada video on the Laplace Expansion Theorem, where a specific didactical approach is used. Beyond the comparison between the results of the two experiments, the findings of this study revealed that most students achieved the leaning objectives and appreciated the quality of the video in terms of image, sound, clarity and useless. The necessity of video contents in teaching was also expressed, mainly to clarify doubts and remember contents. However, all students considered that videos cannot replace traditional face-to-face classrooms, mainly due to the importance of the Teacher-Student dialogue.
\end{abstract}

Index Terms-Educational videos, mathematics, higher education, laplace expansion theorem, user satisfaction, learning.

\section{INTRODUCTION}

With the rapid growth of the Internet and the evolution of Smartphones, the video use in Higher Education (HE) has exponentially increased in the last decade. This trend has been accentuated during the year 2020 with the COVID-19 pandemic, which provided new challenges for the educators who had to adjust their face-to-face lectures and implement online learning [1], [2].

The increasing use of video lectures in HE has resulted in the development of research studies in this area. This technology has been viewed as a tool for enhancing teaching, but also assessment [3]. Motivating [4], [5], useful, helpful, and effective on learning performance [6]-[8], are common expressions that have been used by the students to qualify the educational videos. Furthermore, the possibility of learning anytime, anywhere, and viewing material repetitively if necessary, is also appreciated [9], [10].

Manuscript received May 27, 2021; revised September 26, 2021. This work has been supported by national funds through FCT - Fundação para a Ciência e Tecnologia through project UIDB/04728/2020.

S. F. Costa is with the CIICESI - Center for Research and Innovation in Business Sciences and Information Systems School of Management and Technology (ESTG) of Porto Polytechnic Institute (IPP), 4610-156, Felgueiras, Portugal (e-mail: sfc@estg.ipp.pt).
In contrast, some studies report negative aspects of the video use in education. The technical problems such as excessive file size or lack of smooth Internet network [11], [12], the preference for traditional face-to-face classrooms [13], [14], and the lack of time [15], have been pointed out as obstacles for the use of videos by the students. Moreover, the positive effect on the learning performance is not always the conclusion of the preformed studies [16], and some concern has existed on the relation between the availability of learning videos and the levels of absenteeism. Traphagan $e t$ al. (2010) conducted a study using a geology course of a university, where 153 students were allowed access to lecture videos while 211 students were not. The results of this comparative study suggested that the videos had positive effects on the learning performance, but a decline of the physical attendance was verified. However, the number of studies that report positive aspects of the video use in education is significantly larger [17], and according to many researchers, their benefits overweigh the weaknesses of the technology [18].

It has been observed that students reveal insufficient basic knowledge and lack of motivation in Mathematics [19], which has been viewed as challenging [20] and impractical in everyday life [21]. However, the importance of this science is uncontestable due to its application in numerous areas, such as, engineering, economics, or physics. Some strategies for overcoming this problematic have been proposed in the literature. Among others, the use of technological tools is referred to as a solution for changing the students' perception of Mathematics [22] and enabling students' autonomy in the learning process [23].

The creation of the b-Learning course b-Mat@plicada is one of the strategies implemented in the Portuguese HE institution where this study was performed, to overcome the difficulties of the students in Mathematics. Currently composed of 27 learning videos on differential calculus, integration methods, and matrix calculus, this course is available on the Moodle platform. Thus, all students of the institution have anytime and anywhere access to the contents.

The video files in the educational context can be divided into three groups: the substitutional videos that can complement or replace the face-to-face classes [24], the creative videos that are made by the students themselves, which allows the acquisition of several critical thinking and technology skills [25], [26], and the supplementary videos that allow a reinforcement of learning [27]. In the case of the b-Mat@plicada course, all videos are substitutional since they contain all details of the subject. In a previous study, the 89 surveyed students considered the b-Mat@plicada videos as useful, a great help to remember or understand, and the quality of image and sound was also appreciated [28]. 
Later, an experiment was performed in the classroom context with 49 HE students, who watched once the b-Mat@plicada video on Matrix Multiplication without any previous explanation. With the aim of verifying the achievement of the learning objectives, they posteriorly solved an exercise without support of the teacher or colleagues and then, answered a questionnaire assessing viewing behavior, attitudes, and satisfaction. Findings demonstrated the adequacy of the selected b-Mat@plicada video to achieve the previously defined learning objectives. Furthermore, its quality was appreciated respecting the image and sound quality, the video length, the usefulness, and the effectiveness in helping them to understand the topic.

The use of educational videos by itself does not guarantee a successful learning since their quality is determinant. In the previous study, only $31 \%$ of the surveyed students considered that the videos available on the Internet are, in general, diversified and clear. In fact, the pedagogical techniques used in the video for the step-by-step explanation have a primordial role, especially in Mathematics where students usually have difficulties and present heterogeneous knowledge levels.

In the present study, an analogous experiment was carried out with a larger number of students and a higher difficulty level topic of Mathematics. As proceeded previously, $63 \mathrm{HE}$ students watched the b-Mat@plicada video on the Laplace Expansion Theorem and then solved individually an exercise. Finally, they answered a satisfaction survey that includes new questions to deepen some specific ideas. This research has four aims: i) to propose a pedagogical approach of the Laplace Expansion Theorem; ii) to verify the achievement of the learning objectives of the selected video; iii) to conclude about the students' attitudes and satisfaction respecting the video use in education, and the quality of the selected video; iv) to evaluate the existence of significant differences between the results of the two experiments.

After the description of the didactical approach used in the video on the Laplace Expansion Theorem in Section 2, this paper includes a third section where the procedure of the experiment is described. All results are presented, analyzed, and discussed in the last sections 4 and 5 .

\section{Didactical ApPRoach OF THE Laplace EXPANSION THEOREM}

The Laplace Expansion Theorem, one of the most important properties of determinants [29], allows expressing the determinant of a matrix as a linear combination of determinants of smaller matrices, designated by minors. So, the presentation of the Laplace Expansion Theorem requires first the definitions of minor and cofactor:

Definition 1. If $A$ is a $n \times n$ matrix $(n \geq 2)$ and $a_{i j}$ is the entry of $A$ at the intersection of the $i$-th row and the j-th column, then, the minor of $a_{i j}$, denoted by $M_{i j}$, is the determinant of the sub-matrix obtained from A by deleting its i-th row and its $j$-th column.

An example with a $3 \times 3$ matrix is illustrated in Fig. 1, where the minor $M_{11}$ is calculated.

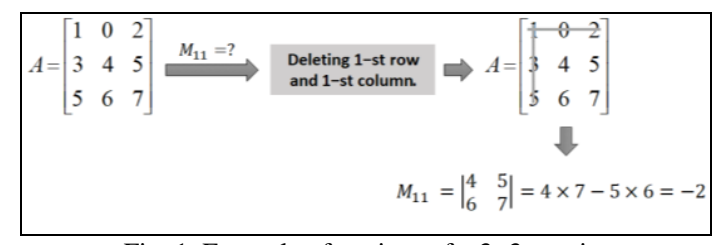

Fig. 1. Example of a minor of a $3 \times 3$ matrix.

Definition 2. If $A$ is a $n \times n$ matrix $(n \geq 2)$ and $a_{i j}$ is the entry of $A$ at the intersection of the $i$-th row and the j-th column, then, the cofactor of $a_{i j}$, denoted by $A_{i j}$, is defined by:

$$
A_{i j}=(-1)^{i+j} M_{i j}
$$

Then, the Laplace Expansion Theorem can be presented:

Theorem. Consider that $A$ is a $n \times n$ matrix $(n \geq 2)$ and $a_{i j}$ is the entry of $A$ at the intersection of the $i$-th row and the $j$-th column. If $A_{i j}$ is the cofactor of $a_{i j}$, then, for any row $i$, the following row expansion holds:

$$
|A|=a_{i 1} A_{i 1}+a_{i 2} A_{i 2}+\ldots+a_{i n} A_{i n}=\sum_{k=1}^{n} a_{i k} A_{i k}
$$

Similarly, for any column $j$, the following column expansion holds:

$$
|A|=a_{1 j} A_{1 j}+a_{2 j} A_{2 j}+\ldots+a_{n j} A_{n j}=\sum_{k=1}^{n} a_{k j} A_{k j}
$$

A possible learning strategy for the Laplace Expansion is the presentation of the definitions and the Theorem, completed by some practical examples. This technique has been adopted in the classroom context but has shown to be inadequate, probably due to the usual reluctance to use theorems [30], [31] and understand algebraic expressions [32]. The minor and cofactor definitions are usually well-assimilated, but the linear combination of minors is regularly misunderstood by the students. Then, some reflection is required with the aim of choosing a more suitable learning strategy, since the difficulties in Mathematics are in part associated to the teaching procedure-based learning [33]. Before the definition of a procedure, it is important to identify what kind of mathematical task we are dealing with.

Two types of mathematical tasks exist: problems and non-problems [34]. When dealing with a problem, the application of the required mathematical actions is not immediately evident, while with a non-problem or exercise, the required mathematical tasks are obvious [35]. In this case, the calculation of a determinant using Laplace Expansion is a non-problem. Consequently, as procedure based-model of teaching, the algorithmic reasoning is selected.

An algorithm is composed by finite sequences of executable instructions to solve a given set of tasks [36]. Since in this case, the objective is to produce an answer for a particular problem, i.e., to write the Laplace Expansion, the use of an algorithm seems to be appropriate. Although some researchers have argued that the use of algorithms avoids the conceptual understanding of the actual problem [37], these save time, prevent miscalculations [38] and can be efficient to learn specific themes [39].

The following algorithm composed of four tasks, illustrated with examples, is then used to apply the Laplace 
Expansion Theorem:

Task 1. Determine the number $n$ of summands $\left(a_{i j} A_{i j}\right)$, which is equal to the dimension of the matrix.

Example: with a matrix of order $n=3$, we will have $n=3$ summands ( $\left.a_{-} A_{--}\right)$:

$$
\left|\begin{array}{ccc}
0 & 3 & 0 \\
6 & 5 & -2 \\
2 & 1 & -2
\end{array}\right|=a_{--} A_{--}+a_{--} A_{--}+a_{--} A_{--}
$$

Task 2. To simplify the calculations, choose the line or the column with more zeros.

Example: considering this matrix, the first line is selected:

$$
\left|\begin{array}{lll}
0 & 3 & 0 \\
6 & 5 & -2 \\
2 & 1 & -2
\end{array}\right|
$$

Task 3. Include the subscript corresponding to the chosen row or column in all variables $a_{i j}$ and $A_{i j}$.

Examples: considering this matrix, where the $1^{\text {st }}$ line was selected:

$$
\left|\begin{array}{lll}
0 & 3 & 0 \\
6 & 5 & -2 \\
2 & 1 & -2
\end{array}\right|=a_{1-} A_{1-}+a_{1-} A_{1-}+a_{1-} A_{1-}
$$

Or, considering this matrix, where the $3^{\text {rd }}$ column was selected:

$$
\left|\begin{array}{llc}
4 & 2 & 0 \\
6 & 5 & 0 \\
7 & 4 & -1
\end{array}\right|=a_{-3} A_{-3}+a_{-3} A_{-3}+a_{-3} A_{-3}
$$

Task 4. Complete, in the remaining subscripts, consecutively, $1,2,3, \ldots ., n$. The final expression is then obtained.

Examples: considering this matrix, where the $1^{\text {st }}$ line was selected:

$$
\begin{aligned}
& \left|\begin{array}{lll}
0 & 3 & 0 \\
6 & 5 & -2 \\
2 & 1 & -2
\end{array}\right|=a_{11} A_{11}+a_{1-} A_{1-}+a_{1-} A_{1-} \\
& \left|\begin{array}{lll}
0 & 3 & 0 \\
6 & 5 & -2 \\
2 & 1 & -2
\end{array}\right|=a_{11} A_{11}+a_{12} A_{12}+a_{1-} A_{1-} \\
& \left|\begin{array}{lll}
0 & 3 & 0 \\
6 & 5 & -2 \\
2 & 1 & -2
\end{array}\right|=a_{11} A_{11}+a_{12} A_{12}+a_{13} A_{13}
\end{aligned}
$$

After accomplishing these tasks, the linear combination of minors for the determinant of any square matrix is obtained. Before the implementation of this algorithm in classes, a more traditional strategy was used, where the definitions and the Theorem were presented, explained, and enriched by some examples. At that time, students always used the Rule of Sarrus to find the determinant of a $3 \times 3$ matrix in the assessment tests, as an alternative to the Laplace Theorem. From the moment that the algorithm was suggested and applied, it has been observed a better assimilation in classes and a much more frequent use of the Laplace Theorem in tests. Thus, since this learning strategy was primarily assessed in the real context of classes and have showed to be more effective, the proposed algorithm was used in the video on the Laplace Expansion Theorem.

\section{METHOD}

\section{A. Sample}

The student sample was selected from a HE institution in Portugal, and consisted of 63 students ( 24 males, 39 females) of the Business Sciences degree, enrolled in the first year Applied Mathematics course. The syllabus of this course is composed of Methods of Integration, Topics of Differential Equations, Matrix Calculus and Systems of Linear Equations. Contrary to the previous experiment, these students are not familiarized with the specific explanation commonly used in the videos since the teacher of the Applied Mathematics course is not the author of the b-Mat@plicada contents.

Despite the relative low number of participants due to the controlled conditions of the experiment, where the video is watched only once and the exercise is solved individually without support, it is believed that this study will allow concluding on the video quality and the achievement of the learning objectives.

\section{B. Instrument}

The selected b-Mat@plicada video is on the Laplace Expansion Theorem, which is included in several Mathematics courses of Engineering and Business Sciences degrees. The video file was produced with the combined use of Microsoft Office PowerPoint and Audacity, as recommended in a previous work where a methodology for creating videos is proposed [40]. The didactical approach described in the last section was followed and the explanation is frequently supported by visual aids such as arrows, underlines, or colours [41], as illustrated in Fig. 2. Each step is carefully described, and many examples are shown to illustrate the tasks of the proposed algorithm.

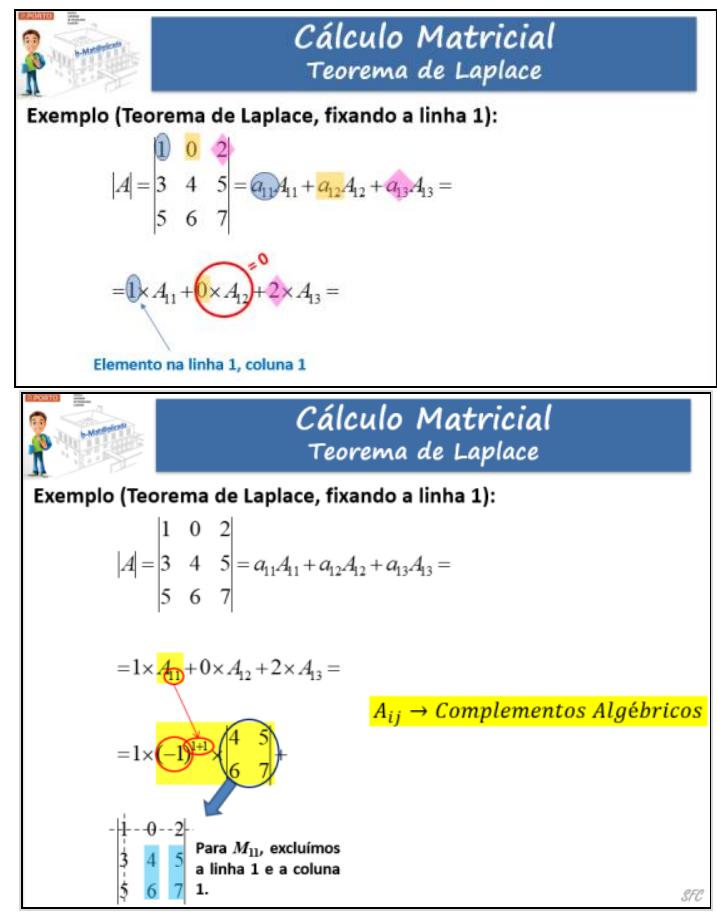

Fig. 2. Examples of visual aids to support the explanation of the video. 
Researchers have agreed that the video length must be minimized to avoid mental fatigue and then increase learning outcomes. Shorter videos have shown to be more engaging [42] and improve learning experience [43]. In line with this concern, the length of allb-Mat@plicada contents are always minimized. In this case, the length of the selected video is 8 minutes and 26 seconds, that is, below 10 minutes as recommended in the literature [43], [44].

\section{Procedure}

The experiment was conducted in the classroom, where all students watched once the selected video, without any previous explanation on the Laplace Expansion Theorem. Then, they were asked to solve individually an exercise, with the aim of verifying the achievement of the learning objectives. Next, the students responded to a satisfaction survey composed of questions on the video use in teaching, and other ones, more specific, related to the quality of the selected video.

\section{Data Analysis}

In a first analysis, descriptive statistics were used to analyse the results obtained from the responses of the students. Next, hypothesis testing was applied to compare these results with the data obtained in the previous experiment with the video on Matrix Multiplication. The existing differences between the conditions of the two experiments can be consulted in Table I. Comparing with the previous experiment, the Laplace Expansion Theorem is a concept with a higher difficulty level, and the students who participated in this experiment are not familiarized with the learning strategy usually adopted by the narrator of the b-Mat@plicada videos. On the other hand, they have generally a higher mathematical knowledge level. The musical introduction of the video on the Laplace Theorem was reduced, due to a previous conclusion from Experiment 1, where students did not express a positive and consensual opinion on this. The objective is to verify if this action improved the opinion of students on the adequacy of the video introduction.

TABLE I: EXISTING DIFFERENCES BETWEEN THE CONDITIONS OF THE TWO EXPERIMENTS

\begin{tabular}{ll}
\hline \hline $\begin{array}{l}\text { Experiment } 1[40] \\
\begin{array}{l}\text { The narrator of the video is } \\
\text { the instructor of the } \\
\text { face-to-face classes. }\end{array}\end{array}$ & $\begin{array}{l}\text { The narrator of the video is not the } \\
\text { instructor of the face-to-face } \\
\text { classes. }\end{array}$ \\
$\begin{array}{l}\text { Topic of the video: Matrix } \\
\text { Multiplication. }\end{array}$ & $\begin{array}{l}\text { Topic of the video: Laplace } \\
\text { Expansion Theorem. }\end{array}$ \\
$\begin{array}{l}\text { Students are enrolled in } \\
\text { Higher Professional } \\
\text { Technical Courses. }\end{array}$ & $\begin{array}{l}\text { Students are enrolled in } \\
\text { Undergraduate Courses. }\end{array}$ \\
$\begin{array}{l}\text { Long musical introduction in } \\
\text { the video (30 seconds). }\end{array}$ & $\begin{array}{l}\text { Short musical introduction in the } \\
\text { video (8 seconds). }\end{array}$
\end{tabular}

\section{E. Research Questions}

The present study was designed to address four key research questions:
1) What is the students' opinion about the video use for their learning?

2) How did students rate the quality of the b-Mat@plicada video on the Laplace Expansion Theorem?

3) Were the learning objectives attained after watching the video?

4) Are there significant differences between the results of the two experiments?

\section{RESUltS}

\section{A. Attitudes and Perception of Students Respecting the Use of Videos for Their Learning}

The first question of the survey allowed concluding that only $14 \%(n=9)$ of the students never use videos available on the Internet to help them in their study. On the other hand, the remaining 54 students use the online videos for educational purposes occasionally $(n=40 ; 63 \%)$ or frequently $(n=14 ; 22 \%)$. Their opinions on the quality of the available videos on the Internet are not consensual, since $38 \%(n=24)$ think that these contents are diversified and clear and $48 \%(n=30)$ have an opposite view. These first questions show that there is a demand for good quality videos by the students to support their learning, as concluded in other studies [45].

Concerning the usefulness of the videos for learning, $98 \%$ $(n=62)$ of students considered that the educational videos are useful and beneficial for their learning. Additionally, they indicated until two advantages of the videos: as observed in Table II, the two most selected benefits are the clarification of doubts and the remembering of contents. The lower frequency related to the $3^{\text {rd }}$ item shows that the videos are not usually seen as a way of missing classes.

\begin{tabular}{|c|c|c|}
\hline Ranking place & Item & $\begin{array}{l}\text { Frequency } \\
(n=117)\end{array}$ \\
\hline $1^{\mathrm{st}}$ & The videos allow me to clarify doubts. & 48 \\
\hline $2^{\text {nd }}$ & $\begin{array}{l}\text { The videos allow me to remember } \\
\text { contents. }\end{array}$ & 38 \\
\hline $3^{\text {rd }}$ & $\begin{array}{l}\text { The videos allow me not to be so } \\
\text { harmed if I miss classes; }\end{array}$ & 21 \\
\hline $4^{\text {th }}$ & The videos help modernize education & 10 \\
\hline $5^{\text {th }}$ & Other & 0 \\
\hline
\end{tabular}

\section{B. Can a Learning Video Replace a Traditional Face-to-Face Class? If Not, Why?}

In the third question of the survey, all students $(n=63$; $100 \%$ ) stated that the educational videos cannot substitute traditional face-to-face classrooms. The next question allowed understanding why students have this perception, by selection of until three reasons for this preference. The results, which can be observed in Table 3, show the importance of the dialogue between the teacher and the student, and between students. Social interactions are the element key that videos 
cannot offer in the learning process and these students attach great importance to these for their study.

TABLE III: ABSOLUTE FREQUENCIES RELATING TO THE REASONS WHY VIDEOS CANNOT REPLACE FACE-TO-FACE CLASSROOMS

\begin{tabular}{lll}
\hline \hline Ranking place & Item & $\begin{array}{l}\text { Frequency } \\
(n=132)\end{array}$ \\
\hline $1^{\text {st }}$ & $\begin{array}{l}\text { The space for dialogue and discussion } \\
\text { between the students and the teacher is } \\
\text { indispensable; }\end{array}$ & 56 \\
& The interactions with my colleagues \\
$2^{\text {nd }}$ & 30 \\
& $\begin{array}{l}\text { are important in my learning; } \\
\text { Face-to-face classes is more } \\
\text { motivating than studying with videos } \\
\text { alone; } \\
4^{\text {th }}\end{array}$ & 23 \\
$5^{\text {th }}$ & $\begin{array}{l}\text { To study with videos, a self-discipline } \\
\text { I do not like using digital technologies } \\
\text { to study; } \\
6^{\text {th }}\end{array}$ & 4 \\
& $\begin{array}{l}\text { Others: } \\
\text { "In the videos, the examples are very } \\
\text { simple and for this reason, I think that } \\
\text { videos cannot substitute face-to-face } \\
\text { classes" }\end{array}$ & \\
\hline \hline
\end{tabular}

\section{Students' Opinions on the Quality of the Selected Video}

The students evaluated the selected video concerning its quality and usefulness through a five-point Likert scale $(1=$ Strongly Disagree, 2 = Somewhat Disagree, 3 = Neither Agree nor Disagree, 4 = Somewhat Agree, $5=$ Strongly Agree). Table IV presents the descriptive statistics of the obtained ratings.

TABLE IV: DESCRIPTIVE STATISTICS OF THE RATINGS ON THE QUALITY OF THE SELECTED VIDEO

$(\mathrm{N}=63$; PeRCENTAGes, MEAN AND StANDARD DEVIATION $)$

\begin{tabular}{|c|c|c|c|c|c|c|c|}
\hline Item & 1 & 2 & 3 & 4 & 5 & M & SD \\
\hline $\begin{array}{l}\text { 1. The video is } \\
\text { clear. }\end{array}$ & 0,0 & 0,0 & 0,0 & 20,6 & 79,4 & 4,8 & 0,6 \\
\hline $\begin{array}{l}\text { 2. The video is } \\
\text { attractive. }\end{array}$ & 0,0 & 1,6 & 14,3 & 46 & 38,1 & 4,2 & 0,8 \\
\hline $\begin{array}{l}\text { 3. The video } \\
\text { helps me to } \\
\text { understand the } \\
\text { subject. }\end{array}$ & 0,0 & 0,0 & 3,2 & 30,2 & 66,6 & 4,6 & 0,7 \\
\hline $\begin{array}{l}\text { 4. I like the } \\
\text { inclusion of } \\
\text { music at the } \\
\text { beginning of the } \\
\text { video. }\end{array}$ & 3,2 & 3,2 & 74,6 & 9,5 & 9,5 & 3,2 & 0,8 \\
\hline $\begin{array}{l}\text { 5. The image } \\
\text { quality is good. }\end{array}$ & 0,0 & 0,0 & 9,5 & 33,3 & 57,2 & 4,5 & 0,8 \\
\hline $\begin{array}{l}\text { 6. The sound } \\
\text { quality is good. }\end{array}$ & 0,0 & 1,6 & 11,1 & 41,3 & 46,0 & 4,3 & 0,8 \\
\hline $\begin{array}{l}\text { 7. This is the } \\
\text { kind of video } \\
\text { that can help me } \\
\text { to study. }\end{array}$ & 0,0 & 1,6 & 3,2 & 22,2 & 73,0 & 4,7 & 0,6 \\
\hline $\begin{array}{l}8 . \text { The examples } \\
\text { used in the } \\
\text { video are } \\
\text { appropriate. }\end{array}$ & 0,0 & 1,6 & 0,0 & 30,2 & 68,2 & 4,7 & 0,7 \\
\hline $\begin{array}{l}\text { 9. The video } \\
\text { length is } \\
\text { adequate. }\end{array}$ & 0,0 & 1,6 & 0,0 & 44,4 & 54,0 & 4,5 & 0,6 \\
\hline $\begin{array}{l}\text { 10. I like the } \\
\text { effects/animatio } \\
\text { ns of the video. }\end{array}$ & 0,0 & 0,0 & 28,6 & 42,8 & 28,6 & 4,0 & 0,8 \\
\hline
\end{tabular}

These results show generally very positive opinions of the students concerning the selected video, more precisely respecting its clarity, adequacy in helping and understanding, image and sound quality, and length. The effects and animations used in the video had a less positive opinion. On the other hand, the lowest mean was observed for the inclusion of music in the video introduction to make it more attractive.

In all b-Mat@plicada videos, a white and clean background is usually used, as suggested previously in the proposed methodology [40]. The students also expressed their opinions on this choice: $81 \%(n=50)$ considered that the white and clean background is adequate because it allows concentrating on what is most important, $11 \%(n=11)$ think that this does not make difference, and only one student (2\%) affirmed that some extra figures on the educational topic, or different colors, could make the video more attractive.

\section{Which Are the Most Important Features in a Learning Video?}

The students selected the three most important characteristics to be considered in a learning video, among seven suggested items: video length, quality of speech, timbre of voice, sound quality, image quality, aesthetic aspects, and animations. Additionally, the students could add another aspect that was not included in the proposed list. The results presented in Table $\mathrm{V}$ allow concluding that, from the students' point of view, the speech $(n=50)$, image $(n=45)$, and sound $(n=36)$ are the main aspects to be considered. The $4^{\text {th }}$ ranking place of the video length shows its relative importance. Contrarywise, the frequencies related to the aesthetic aspects and the animations are lower.

TABLE V: RANKING OF THE MOST IMPORTANT FEATURES IN LEARNING VIDEOS

\begin{tabular}{lll}
\hline \hline Ranking place & Item & $\begin{array}{l}\text { Frequency } \\
(n=178)\end{array}$ \\
\hline $1^{\text {st }}$ & Quality of speech. & 50 \\
$2^{\text {nd }}$ & Quality of image & 45 \\
$3^{\text {rd }}$ & Quality of sound. & 36 \\
$4^{\text {th }}$ & Length of video. & 22 \\
$5^{\text {th }}$ & Timbre of voice & 12 \\
$6^{\text {th }}$ & Animations & 9 \\
$7^{\text {th }}$ & Aesthetic aspects. & 3 \\
$8^{\text {th }}$ & Others: & 1 \\
\hline \hline
\end{tabular}

\section{E. Students' Skills Achievement}

After watching the video, students were asked to solve an exercise, which consists in calculating a given determinant using the Laplace Expansion Theorem. It was verified that $86 \%(n=54)$ correctly solved the proposed exercise, without any mathematical error (Fig. 3). On the other hand, 14\% ( $n=$ 9) suitably applied the Theorem but did not obtain the final correct result due to miscalculations or incorrect calculation of the second-order determinants, as exemplified in Fig. 4. These results allow concluding that the selected video is an appropriate content to achieve the learning objectives. 


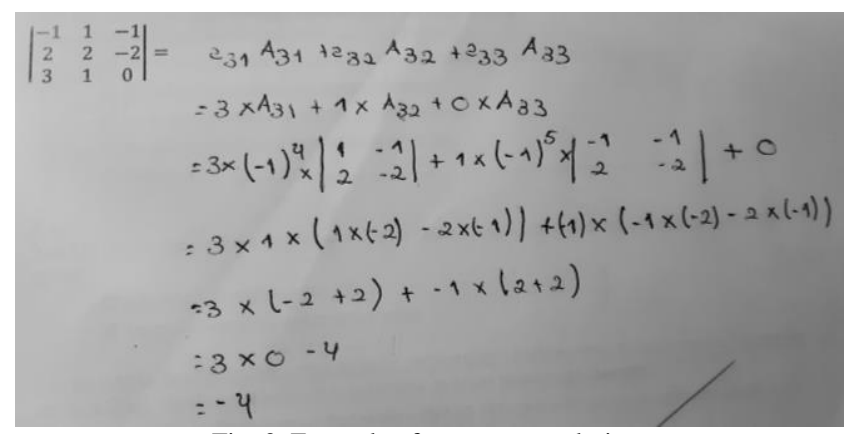

Fig. 3. Example of a correct resolution.

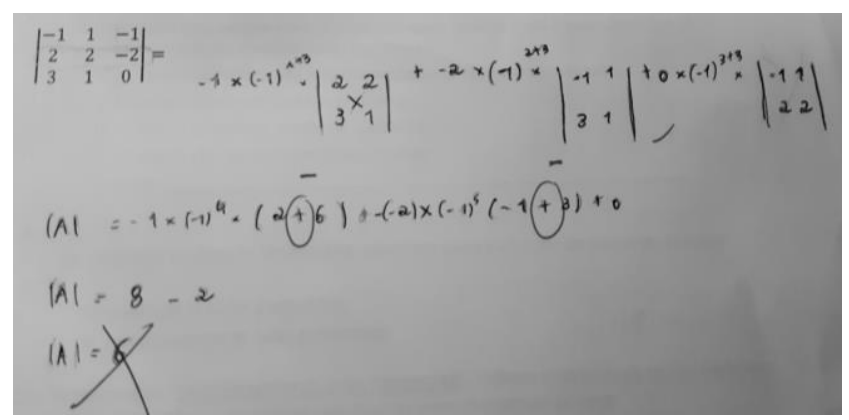

Fig. 4. Example of an incorrect resolution.

\section{DISCUSSION}

In a general way, this study shows the usefulness of the videos for learning. The students revealed a habit of searching videos for their study with the aim of clarifying doubts and remembering contents, even being aware that these have not always a good quality.

The negative effect of the videos on class attendance has been investigated by many researchers since this has been considered as a reason why educators do not incorporate this type of contents in their practice [46]. Although some studies show that many students view the video technology as an alternative to traditional classes [47], most researchers concluded that, in practice, there is not a significant effect of the videos on class attendance [48], [49]. In the present research, despite the helpfulness and the necessity of the learning videos referred by the students, all of them consider the videos as a good complement of the traditional face-to-face classes, not as a substitute, which is in accordance with other studies of the literature [50], [51]. In the previous experiment with the b-Mat@plicada video on the Matrix Multiplication, a high percentage of students with this opinion was also obtained $(90 \%)$ but the reasons for this were not investigated.

Schreiber and co-workers (2010) compared the differences between live lectures and video podcasts by performing an experiment with 100 medical students, divided into two groups; the students of the first group watched a video on vasculitis whilst the students of the other group attended a traditional face-to-face lecture on the same topic. Significate differences between the learning outcomes were not found, but students preferred live lectures. Some comments were obtained about the fact that videos are less engaging: "require discipline", "hard to concentrate", or "less motivated to study", were examples of reasons for this preference [52]. According to the surveyed students of the current study, the absence of Teacher-Student dialogue is the main reason why videos cannot replace the traditional classes. In fact, a largely higher frequency was registered for this item, comparing with the interaction with colleagues, the motivational aspect of classes and the requirement of a self-discipline to study with videos. Only one student added another reason: "In the videos, the examples are very simple and for this reason, I think that video cannot substitute face-to-face classes". In fact, for more knowledgeable students, the examples can be simple and the explanations too slow [53]. However, the presentation of examples with a higher difficulty level implies the elimination of more basic explanations, with the aim of not exceeding the recommended limit for the video length. On the other hand, these basic explanations can be relevant for some students who have more difficulties. This problematic is also present in classes due to the heterogeneity of the levels of Mathematics knowledges of the students. So, the production of many videos on the same topic, but with different difficulty levels, can be a solution for the students who share this opinion and a strategy for increasing the level of knowledge.

Although this preference for classes, the video was sufficient for the students to reach the previously defined objectives, since $86 \%$ could solve the proposed exercise, and the observed incorrect resolutions were not due to an incorrect application of the Theorem. In the previous study with the b-Mat@plicada video on the Matrix Multiplication, most students also correctly solved the proposed exercise. This suggests that the higher difficulty level of the Laplace Theorem, and the fact that the narrator of the videos is not the teacher of the students, did not have a negative effect on the achievement of the learning objectives. Thus, the educational video should be considered as a complement tool of face-to-face lectures that allows reaching the learning objectives, as concluded by Ramlogan et al. (2014). Moreover, the results of the current study also indicate the suitability of the selected procedure based-model of teaching, the algorithmic reasoning. Despite the negative aspects of using algorithms referred by some authors [34], [37], this shows that they can be efficient to learn specific topics, as concluded before by Caron (2007) respecting the multiplication tables.

As referred previously, a similar experiment was performed with another group of students, using the b-Mat@plicada video on Matrix Multiplication. The same video quality items were rated by the students in the two experiments. The results of a $t$-test for independent samples were computed by using the IBM SPSS $®$ software (Table 6), where the equality of variances was assessed by using the Levene's Test $\left(\mathrm{H}_{0}: \mu_{1}=\mu_{2}\right.$ vs. $\mathrm{H}_{1}: \mu_{1} \neq \mu_{2}$; two independent samples; Significance Level: 0,05$)$. These revealed that the ratings assigned by the students in the first experiment are not significantly different from the ratings obtained in this study, except for items 4 and 10, with confidence intervals of [0,305; $0,974]$ and $[0,014 ; 0,620]$ respectively. As referred before, in this second experiment, the topic of the video has a higher difficulty level and the teacher is not the narrator of the video. However, this did not cause significant differences on the students' opinion respecting the videos, which were appreciated at various levels. The good rates obtained in both experiments related to the image and sound quality reveal 
that the software and the equipment used to produce the videos are adequate. On the other hand, the good results related to the clarity, the choice of the examples and the helpfulness, show the adequacy of the selected learning procedure and the techniques applied for the step-by-step explanation. The visual elements used to support the explanation, as recommended in research [41], probably had an important effect on these conclusions, but more research must be performed to confirm this influence. On the contrary, differences were observed respecting the musical introduction of the video and the effects/animations. Even with a reduction of the musical introduction, the opinion on this element persists less positive, with even lower rates. Consequently, with further research, other introduction formats can be included and tested or, the elimination of the musical introduction can be considered in future since it allows a reduction of the video length and production working time.

TABLE VI: SUMMARY OF RESULTS AND OUTCOMES OF HYPOTHESES TESTING

\begin{tabular}{|c|c|c|c|c|}
\hline Item & $\begin{array}{l}\text { Levenne's } \\
\text { test result }\end{array}$ & $T$ & p-value & $\begin{array}{l}\text { Significant } \\
\text { Differences }\end{array}$ \\
\hline $\begin{array}{l}\text { 1. The video is } \\
\text { clear. }\end{array}$ & $\begin{array}{c}\text { Equal } \\
\text { variances } \\
\text { assumed }\end{array}$ & $-1,388$ & 0,168 & $\begin{array}{c}\text { Not } \\
\text { supported }\end{array}$ \\
\hline $\begin{array}{l}2 . \text { The video is } \\
\text { attractive. }\end{array}$ & $\begin{array}{c}\text { Equal } \\
\text { variances } \\
\text { assumed }\end{array}$ & $-0,209$ & 0,834 & $\begin{array}{c}\text { Not } \\
\text { supported }\end{array}$ \\
\hline $\begin{array}{l}\text { 3. The video } \\
\text { helps me to } \\
\text { understand the } \\
\text { subject. }\end{array}$ & $\begin{array}{c}\text { Equal } \\
\text { variances } \\
\text { assumed }\end{array}$ & $-1,223$ & 0,224 & $\begin{array}{c}\text { Not } \\
\text { supported }\end{array}$ \\
\hline $\begin{array}{l}\text { 4. I like the } \\
\text { inclusion of } \\
\text { music at the } \\
\text { beginning of the } \\
\text { video. }\end{array}$ & $\begin{array}{c}\text { Equal } \\
\text { variances not } \\
\text { assumed }\end{array}$ & 3,798 & 0,000 & Supported \\
\hline $\begin{array}{l}5 . \text { The image } \\
\text { quality is good. }\end{array}$ & $\begin{array}{c}\text { Equal } \\
\text { variances } \\
\text { assumed }\end{array}$ & 0,755 & 0,452 & $\begin{array}{c}\text { Not } \\
\text { supported }\end{array}$ \\
\hline $\begin{array}{l}\text { 6. The sound } \\
\text { quality is good. }\end{array}$ & $\begin{array}{c}\text { Equal } \\
\text { variances } \\
\text { assumed }\end{array}$ & 0,798 & 0,426 & $\begin{array}{c}\text { Not } \\
\text { supported }\end{array}$ \\
\hline $\begin{array}{l}\text { 7. This is the } \\
\text { kind of video } \\
\text { that can help me } \\
\text { to study. }\end{array}$ & $\begin{array}{c}\text { Equal } \\
\text { variances } \\
\text { assumed }\end{array}$ & $-0,691$ & 0,491 & $\begin{array}{c}\text { Not } \\
\text { supported }\end{array}$ \\
\hline $\begin{array}{l}\text { 8. The examples } \\
\text { used in the } \\
\text { video are } \\
\text { appropriate. }\end{array}$ & $\begin{array}{c}\text { Equal } \\
\text { variances } \\
\text { assumed }\end{array}$ & $-0,925$ & 0,357 & $\begin{array}{c}\text { Not } \\
\text { supported }\end{array}$ \\
\hline $\begin{array}{l}\text { 9. The video } \\
\text { length is } \\
\text { adequate. }\end{array}$ & $\begin{array}{c}\text { Equal } \\
\text { variances } \\
\text { assumed }\end{array}$ & 0,378 & 0,706 & $\begin{array}{c}\text { Not } \\
\text { supported }\end{array}$ \\
\hline $\begin{array}{l}\text { 10. I like the } \\
\text { effects/animatio } \\
\text { ns of the video. }\end{array}$ & $\begin{array}{c}\text { Equal } \\
\text { variances } \\
\text { assumed }\end{array}$ & 2,074 & 0,040 & Supported \\
\hline
\end{tabular}

In the experiment of the current study, an additional question was included in the survey, respecting the choice of the white and clear background commonly used in the b-Mat@plicada videos. Most students believe that this strategy is adequate since it allows concentrating on what is most important. This is in accordance with the recommendation of Clark and Mayer (2008), who suggest avoiding any element that is not important to the learning objective [53].

Table V shows, for the two experiments, the most important features to be considered in learning videos, according to the students. The quality of speech, sound and image continues in the top-ranking places. The quality of speech, sound and image continues in the top-ranking places. The differences are observed respecting the video length, which is more important for the students who participated in the present study and relating to the aesthetic aspects that occupied a better ranking place in the first experiment. In the present study, one student suggested another feature: the presentation of many different examples. The importance of this item was also expressed by students who participated in other studies [7]. In fact, the presentation of diversified examples is important but cannot be too extensive to avoid a high video length.

TABLE V: RANKING OF THE MOST IMPORTANT FEATURES IN LEARNING VIDEOS

\begin{tabular}{llll}
\hline \hline \multicolumn{3}{l}{ EXPERIMENT 1 } & \multicolumn{2}{l}{ EXPERIMENT 2 } \\
\hline \hline $\begin{array}{l}\text { Ranking } \\
\text { place }\end{array}$ & Item & $\begin{array}{l}\text { Ranking } \\
\text { place }\end{array}$ & Item \\
\hline $1^{\text {st }}$ & Quality of speech. & $1^{\text {st }}$ & Quality of speech. \\
$2^{\text {nd }}$ & Quality of sound. & $2^{\text {nd }}$ & Quality of image. \\
$3^{\text {rd }}$ & Quality of image. & $3^{\text {rd }}$ & Quality of sound. \\
$4^{\text {th }}$ & Aesthetic aspects. & $4^{\text {th }}$ & Length of video. \\
$5^{\text {th }}$ & Length of video. & $5^{\text {th }}$ & Timbre of voice. \\
$6^{\text {th }}$ & Animations. & $6^{\text {th }}$ & Animations. \\
$7^{\text {th }}$ & Timbre of voice. & $7^{\text {th }}$ & $\begin{array}{l}\text { Aesthetic aspects. } \\
\end{array}$ \\
& & $8^{\text {th }}$ & $\begin{array}{l}\text { Others: } \\
\text { "'Many different } \\
\end{array}$ \\
\hline \hline
\end{tabular}

\section{CONCLUSIONS}

The increasing use of the learning videos in HE led to a growing interest of the researchers in this area, all with the same objective: to understand if and how the videos can help and improve the learning of the students. This concern is even more important in Mathematics, where the difficulties of students are well-known.

In the present study, an experiment was carried out with the b-Mat@plicada video on the Laplace Expansion Theorem, where a group of students watched the video instead of the common face-to-face explanation, solved an exercise and responded to a satisfaction survey. The main objectives are to verify if the learning objectives were achieved and to collect opinions of the students. Other purposes of this work are to propose a procedure based-learning for the Laplace Expansion Theorem and, since a similar experiment was previously made with the b-Mat@plicada video on the Matrix Multiplication, to compare the results of the two experiments.

The obtained responses of the students allowed concluding that the learning videos are useful and helpful for their learning. Despite the concern on the negative effect of the videos on the class attendance presented in some studies, for these students, the videos are only a benefited complement of the face-to-face classes, as verified in the last experiment. 
The reasons for this preference seem to be associated to Teacher-Student dialogue.

Respecting the achievements of the learning objectives, most students were capable to apply the Theorem after the video watching, as observed in the previous experiment and despite a higher difficulty level. This conclusion indicates the adequacy of the didactical approach and the techniques used in the step-by-step explanation.

As observed in the first experiment, the students rated the selected video as useful, helpful, clear and with a good quality of image and sound. Significative differences between the rates attributed by the students were only found respecting the musical introduction and the effects/animations of the video. Further research is required to evaluate which or if video introduction is appropriate for making the video more engaging.

Finally, from these students' view, the main features to be considered in a learning video are the speech, image and sound. These three items were also chosen by the students who participated in the first experiment. The differences were only observed respecting the video length, which has a higher influence for these students, and the aesthetic aspects that has a low impact.

Further research can be made to understand which elements of the videos can be changed to improve their quality. As an example, the elimination of the musical introduction is an option that must be considered and tested. Moreover, experiments can be performed with a larger number of students and the inclusion of more open-ended questions in the survey to increase the range of answers. The Teacher-Student dialogue was chosen as the main reason why videos cannot replace classes, among several proposed reasons. Even with the possibility of adding another, students may tend to make only a choice. Topics with higher difficulty level can also be evaluated since a different subject implies a different learning strategy, whose efficiently must be evaluated. All these actions have as main objective the improvement of the learning experience of students in Mathematics, which may, one day, cease to be viewed as a challenge.

\section{CONFLICT OF INTEREST}

The author declares no conflict of interest.

\section{AUTHOR CONTRIBUTIONS}

The author had conducted the research and finish this paper; Author had approved the final version.

\section{ACKNOWLEDGMENT}

This work has been supported by national funds through FCT - Fundação para a Ciência e Tecnologia through project UIDB/04728/2020.

The author would like to thank Dr. Ana Borges for her permission and availability to concretize the experiment for this research study.

\section{REFERENCES}

[1] J. R. Bryson and L. Andres, "Covid-19 and rapid adoption and improvisation of online teaching: curating resources for extensive versus intensive online learning experiences," Journal of Geography in Higher Education, vol. 44, no. 4, pp. 608-623, 2020.

[2] J. Kim, "Learning and teaching online during Covid-19: Experiences of student teachers in an early childhood education practicum," IJEC, vol. 52, pp. 145-158, 2020.

[3] L. C. McSwiggan and M. Campbell, "Can podcasts for assessment guidance and feedback promote self-efficacy among undergraduate nursing students? A qualitative study," Nurse Education Today, vol. 49, pp. 115-121, 2017.

[4] E. Alpay and S. Gulati, "Student-led podcasting for engineering education," Eur. J. of Eng. Educ., vol. 35, no. 4, pp. 415-427, 2010.

[5] M. Carmichael, A. K. Reid, and J. Karpicke, "Assessing the impact of educational video on student engagement, critical thinking and learning: The current state of play," SAGE Publishing, 2018.

[6] S. Lonn and S. D. Teasley, "Podcasting in higher education: What are the implications for teaching and learning?" vol. 12, no. 3, pp. 88-92, 2009.

[7] M. Flood, J. C. Hayden, B. Bourke, P. J. Gallagher, and S. Maher, "Design and evaluation of video podcasts for providing online feedback on formative pharmaceutical calculations assessments," American Journal of Pharmaceutical Education, vol. 81, no. 10, pp. 100-103, 2017.

[8] J. Nagy, "Evaluation of online video usage and learning satisfaction: An extension of the technology acceptance model," International Review of Research in Open and Distributed Learning, vol. 19, no. 1, pp. 160-185, 2018.

[9] S. Ramlogan, V. Raman, and J. Sweet, "A comparison of two forms of teaching instruction: Video vs. live lecture for education in clinical periodontology," European Journal of Dental Education, vol. 18, no. 1, pp. 31-38, 2014.

[10] E. Taslibeyaz, M. Aydemir, and S. Karaman, "An analysis of research trends in articles on video usage in medical education", Education and Information Technologies, vol. 22, no. 3, pp. 873-881, 2017.

[11] A. Chester, A. Buntine, K. Hammond, and L. Atkinson, "Podcasting in education: Student attitudes, behaviour and self-efficacy," Educational Technology \& Society, vol. 14, no. 2, pp. 236-247, 2011.

[12] A. Nadhianty and A. Purnomo, "Implementation podcast and learning video to connecting in distance learning on higher education," in Proc. International Conference on Islamic Education, vol. 5, pp. 24-29, 2020.

[13] B. W. O'Bannon, J. K. Lubke, J. L. Beard, and V. G. Britt, "Using podcasts to replace lecture: Effects on student achievement," Computers \& Education, vol. 57, no. 3, pp. 1885-1892, 2011.

[14] S. Winterbottom, "Virtual lecturing: Delivering lectures using screencasting and podcasting technology," Planet, vol. 18, pp. 6-8, 2007.

[15] J. L. Hill and A. Nielsen, "New technology, new pedagogy? Employing video podcasts in learning and teaching about exotic ecosystems," Environmental Education Research, vol. 17, no. 3, pp. 393-408, 2011.

[16] P. Bennett and P. Glover, "Video streaming: Implementation and evaluation in an undergraduate nursing program," Nurse Education Today, vol. 28, no. 2, pp. 253-258, 2008.

[17] R. Kay, "Exploring the use of video podcasts in education: A comprehensive review of the literature," Computers in Human Behavior, vol. 28, pp. 820-831, 2012.

[18] J. P. Schim, J. Shropshire, S. Park, H. Harris, and N. Campbell, "Podcasting for e-learning, communication, and delivery," Industrial Management and Data Systems, vol. 107, no. 4, pp. 587-600, 2007.

[19] B. Abramovitz, A. Bererman, and L. Shvartsman, "A blended learning approach in mathematics," Teaching Mathematics Online: Emergent Technologies and Methodologies, pp. 22-42, 2012.

[20] A. T. Morgan, "A study of the difficulties experienced with mathematics by engineering students in higher education," International Journal of Mathematical Education in Science and Technology, vol. 21, no. 6, pp. 975-988, 1990.

[21] E. P. Marpa, "Common errors in algebraic expressions: A Quantitative-qualitative analysis," International Journal on Social and Education Sciences, vol. 1, no. 2, pp. 63-72, 2019.

[22] M. C. Borba et al., "Blended learning, e-learning and mobile learning in mathematics education," ZDM Mathematics Education (Berlin. Print), vol. 48, pp. 589-610, 2016.

[23] M. Abdulwahed, B. Jaworski, and A. Crawford, "Innovative approaches to teaching mathematics in higher education: a review and critique," Nordic Studies in Mathematics Education, vol. 17, no. 2, pp. 49-68, 2012.

[24] S. B. Heilesen, "What is the academic efficacy of podcasting?" Computers \& Education, vol. 55, pp. 1063-1068, 2010. 
[25] M. Frydenberg, "Principles and pedagogy: The two ps of podcasting in the information technology classroom," Information Systems Education Journal, vol. 6, no. 6, ISSN: 1545-679X, 2008.

[26] M. Lazzari, "Creative use of podcasting in higher education and its effect on competitive agency," Computers \& Education, vol. 52, pp. 27-34, 2009.

[27] K. Crippen and B. Earl, "The impact of Web-based worked examples and self-explanation on performance, problem solving, and self-efficacy," Computers \& Education, vol. 49, no. 3, pp. 809-821, 2007.

[28] S. F. Costa, “"b-Mat@plicada”: A b-learning mathematics course in higher education," ICERI2017 Proceedings, pp. 8966-8973, 2017

[29] M. JanjiÄ, “A note on Laplace's expansion theorem,” International Journal of Mathematical Education in Science and Technology, vol. 36, no. 6, pp. 696-698, 2005.

[30] A. H. Schoenfeld, "Explorations of students' mathematical beliefs and behavior," Journal for Research in Mathematics Education, vol. 20, no. 4, pp. 338-355, 1989.

[31] O. Hazzan and U. Leron, "Students' use and misuse of mathematical theorems: The case of Lagrange's Theorem," For the Learning of Mathematics, vol. 16, no. 1, pp.23-26, 1996.

[32] K. Subramaniam, "Naming practices that support reasoning about and with expressions," Regular Lecture Presented at ICME-10, Denmark, 2004.

[33] B. Jonsson, M. Norqvist, Y. Liljekvist, and J. Lithner, "Learning mathematics through algorithmic and creative reasoning," The Journal of Mathematical Behavior, vol. 36, pp. 20-32, 2014.

[34] J. Boesen, O. Helenius, J. Lithner, E. Bergqvist, T. Bergqvist, T. Palm et al., "Developing mathematical competence: From the intended to the enacted curriculum," Journal of Mathematical Behavior, vol. 33, pp. 72-87, 2014.

[35] K. Weber, "Problem-solving, proving, and learning: The relationship between problem-solving processes and learning opportunities in the activity of proof construction," Journal of Mathematical Behavior, vol. 24, no. 3-4, pp. 351-360, 2005.

[36] G. Brousseau, Theory of Didactical Situations in Mathematics, Dordrecht: Kluwer, 1997.

[37] J. Lithner, "A research framework for creative and imitative reasoning," Educational Studies in Mathematics, vol. 67, no. 3, pp 255-276, 2008.

[38] B. Jonsson, M. Norqvist, Y. Liljekvist, and J. Lithner, "Learning mathematics through algorithmic and creative reasoning," Journal of Mathematical Behavior, vol. 36, pp. 20-32, 2014.

[39] T. A. Caron, "Learning multiplication: The easy way," The Clearing House: A Journal of Educational Strategies, Issues and Ideas, vol. 80, no. 6, pp. 278-282, 2007

[40] S. F. Costa, E. Costa e Silva, and A. Correia, "Guidelines for creating video podcasts in mathematics higher education," The International Journal for Technology in Mathematics Education, vol. 28, no. 2, 2021.

[41] E. Werb, Teach for Attention!: A Tool Belt of Strategies for Engaging Students with Attention Challenges, Minneapolis, MN: Free Spirit Publishing Inc, 2019.

[42] P. E. Doolittle, L. H. Bryant, and J. R. Chittum, "Effects of degree of segmentation and learner disposition on multimedia learning," British Journal of Educational Technology, vol. 46, no. 6, pp. 1333-1343, 2015.
[43] Z. Pi and J. Hong, "Learning process and learning outcomes of video podcasts including the instructor and ppt slides: A Chinese case," Innovations in Education and Teaching International, vol. 53, no. 2, pp. 135-144, 2016.

[44] S. Hubackova, "The use of podcasting in University education," Procedia - Social and Behavioral Sciences, vol. 83, pp. 309-312, 2013

[45] A. Clifton and C. Mann, "Can YouTube enhance student nurse learning?" Nurse Education Today, vol. 31, pp. 311-313, 2011.

[46] T. Traphagan, J. V. Kucsera, and K. Kishi, "Impact of class lecture webcasting on attendance and learning," Educational Technology Research and Development, vol. 58, no. 1, pp. 19-37, 2010.

[47] J. Brotherton and G. Abowd, "Lessons learned from eclass: Assessing automated capture and access in the classroom," ACM Transactions on Computer-Human Interaction, vol. 11, no. 2, pp. 121-155, 2004.

[48] D. Harley, J. Henke, S. Lawrence, F. McMartin, M. Maher, M. Gawlik et al. "Costs, culture, and complexity: An analysis of technology enhancements in a large lecture course at UC Berkeley," California: Center for Studies in Higher Education, 2003.

[49] M. Maag, "iPod, uPod? An emerging mobile learning tool in nursing education and students' satisfaction," in Proc. the 23rd Annual Ascilite Conference: Who's Learning? Whose Technology? pp. 483-492, 2006.

[50] J. Copley, "Audio and video podcasts of lectures for campus-based students: production and evaluation of student use," Innovations in Education and Teaching International, vol. 44, no. 4, pp. 387-399.

[51] V. Parson, P. Reddy, J. Wood, and C. Senior, "Educating an iPod generation: Undergraduate attitudes, experiences and understanding of vodcast and podcast use," Learning, Media and Technology, vol. 34, no.3, pp. 215-228, 2009.

[52] B. E. Schreiber, J. Fukuta, and F. Gordon, "Live lecture versus video podcast in undergraduate medical education: A randomised controlled trial," BMC Medical Education, vol. 10, no. 68, pp. 1-6, 2010.

[53] R. C. Clark and R. E. Mayer, E-Learning and the Science of Instruction, San Francisco: Pfeiffer, 2008.

Copyright (C) 2022 by the authors. This is an open access article distributed under the Creative Commons Attribution License which permits unrestricted use, distribution, and reproduction in any medium, provided the original work is properly cited (CC BY 4.0).

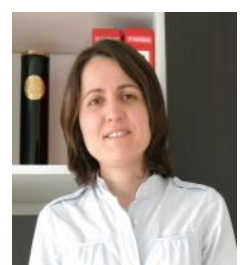

Sidonie F. Costa received her degree in mathematics teaching from University of Minho (UM), Portugal, in 2005, her specialization in mathematics and mechanical applications in 2006 and her $\mathrm{PhD}$ in polymer and composite science and engineering in 2013, from the UM. Since 2010, she is adjunct professor in the Department of Exact Sciences of the School of Management and Technology (ESTG), Porto Polytechnic Institute (P.PORTO), Portugal, and currently an integrated member of the Center for Innovation and Research in Business Sciences and Information Systems (CIICESI), ESTG, P.PORTO. Her experience includes the mathematical modeling of engineering problems, particularly in the area of rapid prototyping, as evidenced by several international conference participations and publications in this area. In parallel, she created the "b-Mat@plicada" project at ESTG, a b-learning course consisting of several educational videos on mathematical topics to assist students in their study. This project led to the development of research studies on the impact of the video use in Higher Education. 